\title{
Arsitektur Sistem Informasi Sekolah
}

\author{
Hafid Khoiruddin' ${ }^{1}$ Bayu Triharyanto ${ }^{2}$, Erwin Kristian Putra ${ }^{3}$, M. Ainul Yaqin ${ }^{4}$ \\ 1,2,3,4Jurusan Teknik Informatika, Fakultas Sains dan Teknologi \\ Universitas Islam Negeri Maulana Malik Ibrahim Malang \\ 116650002@student.uin-malang.ac.id, 2bayutriharyanto@gmail.com,3erwindchristian@gmail.com, \\ 4yaqinov@ti.uin-malang.ac.id
}

\begin{abstract}
The design of school information systems enterprise architecture is carried out to find detailed information about school activities based on government regulatory standards. So that the existing information system in the school business is in accordance with the existing standards of the government and there will be no errors in school activities later, a research is carried out that implements TOGAF ADM as a method in building the architecture of school information systems enterprise. Then the results obtained by business architecture include PSB (Acceptance of New Students), PA (Academic Process), PS (Release of Students), MTU (Management of Administration), MSP (Management of Facilities and Infrastructure), LAB (Laboratory), and the acquisition of architecture data, application architecture and technology architecture. So it can be concluded that the TOGAF ADM Method was successfully implemented in the School Information System Architecture and the School Information System Architecture can be used as a guide in the development and development of information systems in terms of data and information management in schools.
\end{abstract}

Keyword: TOGAF, TOGAF ADM, School Information System

\section{Abstrak}

Perancangan arsitektur enterprise sistem informasi sekolah dilakukan untuk mengetahui informasi secara detail mengenai aktivitas-aktivitas sekolah berdasarkan standar peraturan pemerintah. Agar pada sistem informasi yang ada pada bisnis sekolah sesuai dengan standar yang ada pada pemerintah serta tidak terjadi kekeliruan pada aktivitas sekolah nantinya, maka dilakukan penelitan yang mengimplementasikan TOGAF ADM sebagai metode dalam membangun perancangan arsitektur enterprise sistem informasi sekolah. Maka hasil yang didapatkan arsitektur bisnis yang meliputi PSB (Penerimaan Siswa Baru), PA (Proses Akademik), PS (Pelepasan Siswa), MTU (Manajemen Tata Usaha), MSP (Manajemen Sarana dan Prasarana), LAB (Laboratorium), serta didapatkannya arsitektur data, arsitektur aplikasi dan arsitektur teknologi. Sehingga dapat disimpulkan bahwasannya Metode TOGAF ADM berhasil diimplementasikan dalam Arsitektur Sistem Informasi Sekolah dan Arsitektur Sistem Informasi Sekolah dapat digunakan sebagai pedoman dalam pembangunan dan pengembangan sistem informasi dalam hal pengelolaan data dan dan informasi dalam sekolah.

Kata kunci: TOGAF, TOGAF ADM, Sistem Informasi Sekolah

\section{PENDAHULUAN}

Pada aktivitas sebuah sekolah sudah seharusnya memiliki suatu sistem informasi yang sesuai dengan standart yang dimiliki oleh sekolah tersebut. Namun tidak hanya pada sistem informasi sekolah saja, didalam sistem informasi sekolah terdapat arsitektur sistem informasi sekolah yang memiliki cakupan lebih dalam terhadap sistem informasi sekolah tersebut. Tujuan dari arsitektur sistem informasi sekolah tersebut adalah agar didapatkannya sistem informasi mendetail terhadap seluruh aktivitas sekolah tersebut sehingga aktivitas yang diinginkan bisa berjalan dengan lancar. Setiap sistem informasi memiliki struktur yang berbeda-beda antara simtem informasi yang satu dengan yang lainnya, selian itu 
pada setiap sistem informasi memiliki standart yang berbeda-beda pula hal ini dilakukan karena setiap aktivitas di sekolah memiliki proporsinya masing-masing. Seperti pada peraturan menteri pendidikan dan Kebudayaan Nomor 20 Tahun 2016 tentang standar kompetensi lulusan pendidikan dasar dan menengah lalu pada peraturan Menteri pendidikan dan Kebudayaan Nomor 22 Tahun 2016 tentang standar proses pendidikan dasar dan menengah serta beberapa standard an peraturan pemeritah lainnya.

Pada penelitian ini metode yang digunakan adalah TOGAF, yang awalnya TOGAF digunakan oleh Departemen Pertahanan Amerika Serikat namun pada perkembangannya TOGAF banyak digunakan pada berbagai bidang seperti perbankan, industri manufaktur dan juga pendidikan. TOGAF ini digunakan untuk mengembangkan Enterprise Architecture, dimana terdapat metode dan tools yang detil untuk mengimplementasikannya, hal inilah yang membedakan dengan Framework EA lain misalnya Framework Zachman. TOGAF memberikan metode yang detail bagaimana membangun dan mengelola serta mengimplementasikan arsitektur enterprise dan sistem informasi yang disebut dengan Architecture Development Method (ADM).

\section{METODOLOGI PENELITIAN}

\subsection{Konsep Dasar Sistem Informasi}

Terdapat banyak pengertian sistem informasi menurut beberapa ahli, diantaranya sebagai berikut:

Pengertian menurut [1], Sistem informasi adalah "sebuah rangkaian prosedur formal dimana data dikelompokkan, diproses menjadi informasi, dan didistribusikan kepada pemakai". Sedangkan menurut [3], Sistem informasi adalah cara-cara yang diorganisasi untuk mengumpulkan, memasukkan, dan mengolah serta menyimpan data, dan cara-cara yang diorganisasi untuk menyimpan, mengelola, mengendalikan, dan melaporkan informasi sedemikian rupa sehingga sebuah organisasi dapat mencapai tujuan yang telah ditetapkan.

Sistem informasi adalah suatu sistem didalam suatu organisasi yang mempertemukan kebutuhan pengolahan transaksi harian yang mendukung fungsi operasi organisasi yang bersifat manajerial dengan kegiatan strategi dari suatu organisasi untuk dapat menyediakan kepada pihak luar tertentu dengan laporanlaporan yang diperlukan [3].

Dari kedua pendapat diatas, dapat disimpulkan bahwa sistem informasi merupakan sebuah rangkaian prosedur formal yang diorganisasi untuk mengumpulkan, memasukkan dan mengolah data dan menyampaikan informasi sesuai dengan tujuan yang telah ditetapkan.

\subsection{Arsitektur Enterprise}

Enterprise Architecture (EA) dapat didefinisikan sebagai sebuah blue print [5] yang menjelaskan bagaimana semua elemen TI dan manajemen bekerja bersama dalam satu kesatuan dan memberikan gambaran eksplisit mengenai hubungan antara proses manajemen dengan TI yang sekarang dan yang diharapkan. Jika dikaitan dengan enterprise, maka EA harus memberikan strategi 
yang memungkinkan organisasi mendukung keadaan yang sekarang dan juga bertindak sebagai roadmap menuju lingkungan yang ditargetkan.

\subsection{TOGAF}

TOGAF merupakan sebuah kerangka terperinci dan sekumpulan perangkat pendukung untuk mengembangkan sebuah arsitektur teknologi informasi. Kerangka menyediakan sebuah klasifikasi untuk menghubungkan konsep-konsep yang menggambarkan dunia nyata pada konsep sistem informasi dan implementasinya. Kerangka digunakan untuk menjelaskan keseluruhan perusahaan dan untuk menyimpan informasi tersebut, biasanya didukung oleh perangkat tempat penyimpanan yang tepat.

ADM merupakan metode generik yang berisikan sekumpulan aktivitas yang digunakan dalam memodelkan pengembangan arsitektur enterprise. Metode ini juga dibisa digunakan sebagai panduan atau alat untuk merencanakan, merancang, mengembangkan dan mengimplementasikan arsitektur sistem informasi untuk organisasi [6].

\subsection{Value Chain}

Menurut [7-8], value chain merupakan teknik untuk mendapatkan dan mengembangkan cara bagaimana perusahaan beroperasi. Selain itu juga untuk memisahkan apa yang perusahaan lakukan dan bagaimana perusahaan melakukannya. Value chain terbagi atas dua bagian besar yaitu:

a. Aktivitas utama adalah semua hal yang membuat perusahaan memenuhi perannya dalam value chain industri dan membangun kepuasan terhadap pelanggan, sebagai pihak yang melihat secara langsung pengaruh dari seberapa baik aktivitas-aktivitas tersebut dilakukan.

b. Aktivitas pendukung adalah semua hal yangpenting untuk mengawasi dan membangun bisnis sepanjang waktu dan secara tidak langsung menambah nilai.

\subsection{Kerangka Penelitian}

Pada kerangka penelitian memiliki 4 tahapan sebagai berikut :

\section{a. Identifikasi Masalah}

Dalam tahap ini dilakukan suatu identifikasi terhadap permasalahan yang ada dengan merumuskan masalah yang akan diteliti. Perumusan masalah ini akan menjadikan penelitian menjadi lebih jelas dan terarah.

\section{b. Studi Literatur}

Pada tahap ini dilakukan dengan mempelajari serta memahami teori-teori yang menjadi pedoman serta referensi untuk menyelesaikan masalah yang terjadi dalam penelitian dan mempelajari penelitian-penelitian terdahulu yang terkait dengan topic penelitian. 


\section{c. Mengumpulkan data}

Pengumpulan data dilakukan pada tahap ketiga dengan data-data yang dikumpulkan berhubungan dengan organisasi yang diteliti. Cara pengumpulan data pun dapat dilakukan dengan pengamatan dan wawancara kepada pihak terkait.

\section{d. Membuat Arsitektur TOGAF}

Tahap selanjutnya dengan cara membuat sistem informasi dengan menggunakan metodologi TOGAF ADM (The Open Group Architecture Development Method).

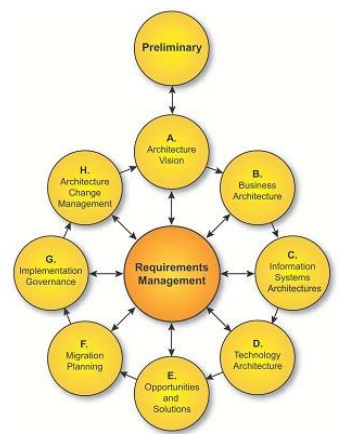

Gambar 1. TOGAF ADM

Tahapan TOGAF seperti dibawah ini:

a. Fase A : Visi Arsitektur

Tahap ini merupakan tahap penggambaran awal dari pengembangan arsitektur yang mencakup pendefinisian ruang lingkup yang dirancang, visi misi serta profil organisasi.

b. Fase B : Arsitektur Bisnis

Fase ini mendefinisikan kondisi awal dalam arsitektur bisnis dengan menentukan arsitektur bisnis dan analisis kesenjangan antara keduanya.

c. Fase C : Arsitektur Sistem Informasi

Fase dimana dibangunnya sistem informasi dimana meliputi 2 arsitektur yaitu data dan aplikasi. Arsitektur Data melakukan identifikasi entitas data dan menggambarkan asosiasi data dengan proses skema. Sedangkan Arsitektur Aplikasi dibuat berdasarkan kebutuhan dan relevan dengan Enterprise Continum.

d. Fase D : Arsitektur Teknologi

Fase ini merupakan fase dimana pembangunan teknologi yang menjadi dasar implementasi sistem. Teknologi diproyeksikan dengan penjelasan detail penggunaannya dalam organisasi.

e. Fase E : Peluang dan Solusi

Tahap dimana terjadinya identifikasi dari arsitektur sebelumnya yang digunakan untuk mencapai rancangan arsitektur

f. Fase F : Perencanaan Migrasi

Tahap dimana roodmap disusun dan pemilihan proyek-proyek implementasi berdasarkan prioritas utama. 
g. Fase G : Tata kelola Implementasi

Fase yang digunakan untuk menyusun tata laksana implementasi serta menyusun manajemen proyek dalam suatu sistem.

h. Fase H : Arsitektur Manajemen Perubahan

Tahap dimana pembangunan suatu manajemen perubahan bagi dasar arsitektur yang baru.

Kedelapan tahapan utama tersebut didukung oleh tahapan persiapan (preliminary) dan tahapan manajemen prasyarat (requirement management) di akhir proses.

a. Preliminary Phase: Framework and Principles

Fase Preliminary merupakan fase awal yang merupakan persiapan sebelum merencanakan sebuah arsitektur enterprise, fase ini bertujuan untuk menjelaskan setiap tahapan-tahapan dari kerangka kerja serta metodologi dari setiap perencanaan, melaksanakan tools arsitektur dan prinsip-prinsip Arsitektur Enterprise

b. Requirement Management

Tahapan ini bertujuan untuk menyediakan proses pengelolaan kebutuhan arsitektur sepanjang fase pada siklus ADM, mengidentifikasi kebutuhan enterprise, menyimpan lalu memberikannya kepada fase yang relevan

\section{HASIL DAN PEMBAHASAN}

\section{a. Lingkup Organisasi}

Pendefinisian lingkup enterprise organisasi atau area bisnis pada sistem informasi sekolah digambarkan dengan menggunakan value chain diagram yang terdapat pada Gambar berikut:

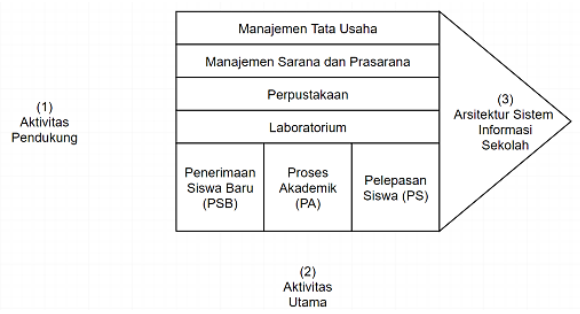

Gambar 2. value chain diagram lingkup organisasi/area bisnis

\section{b. Arsitektur Bisnis dari SI sekolah menjadi sebuah gambar berikut:}

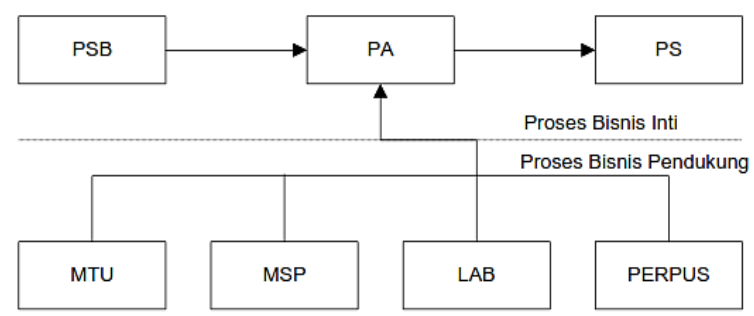

Gambar 3. arsitektur bisnis SI sekolah 
Pada alur proses gambar diatas dijelaskan bahwasannya ada tiga proses bisnis sekolah secara umum yaitu yang pertama adalah proses Penerimaan siswa Baru (PSB) proses ini dilakukan pada tahun ajaran baru untuk menerima peserta didik baru yang mana peserta didik baru harus melakukan beberapa seleksi sehingga bisa dikatakan sebagai siswa baru pada sekolah tersebut.

Selajutnya yaitu Proses Akademik (PA) pada proses ini siswa melakukan kegiatan belajar serta ujian untuk kenaikan kelas serta proses akademik yang lainnya. Setelah kedua proses diatas proses terakhir adalah proses Pelepasan Siswa (PS) pada proses ini siswa telah berada diproses akhir setelah menjalani proses akademik. Selain tiga proses tersebut ada beberapa proses pendukung lainnya seperti MTU, MSP, dan LAB. Manajemen Tata Usaha (MTU) merupakan proses pendukung yang menangani perihal administrasi pada sekolah. Manajemen Sarana dan Prasarana, proses pendukung yang melakukan pengadaan dan pewaratan pada sarana dan prasarana yang ada disekolah seperti pengadaan dan perawatan meja atau kursi pada setiap kelas, pengadaan dan perawatan pada kebun atau lapangan sekolah, serta pengadaan dan perawatan pada sarana prasarana lainnya.

Laboratorium yaitu proses pendukung yang berperan pada penyediaan dan pengawas pada setiap laboratorium seperti laboratorium bahasa, laboratorium computer, dan laboratorium MIPA.

Ket:

PSB : Penerimaan Siswa Baru

PA : Proses Akademik

PS : Pelepasan Siswa

MTU : Manajemen Tata Usaha

MSP : Manajemen Sarana dan Prasarana

LAB : Laboratorium

\section{c. Arsitektur Data}

Tabel 1. Entitas Data

\begin{tabular}{|c|l|}
\hline Entitas Bisnis & \multicolumn{1}{|c|}{ Entitas Data } \\
\hline Penerimaan Siswa Baru & Panitia PPDB \\
& Calon siswa baru \\
& Anggaran PSB \\
& Jadwal Seleksi \\
& Persyaratan Seleksi \\
& Proses Seleksi \\
& Hasil Seleksi \\
& Daftar Ulang \\
\hline Proses Akademik & Kalender akademik \\
& Siswa \\
& Guru \\
& Guru wali kelas \\
& Kurikulum \\
& Jadwal pelajaran \\
& Mata pelajaran \\
& Daftar hadir \\
& Kelas \\
\hline
\end{tabular}


Jurnal Riset Sistem Informasi Dan Teknik Informatika (JURASIK)

Volume 5 Nomor 1 Februari, pp 58-67

ISSN: 2527-5771/EISSN: 2549-7839

http://tunasbangsa.ac.id/ejurnal/index.php/jurasik

\begin{tabular}{|c|l|}
\hline Entitas Bisnis & \multicolumn{1}{|c|}{ Entitas Data } \\
\hline & Soal ujian \\
& Jadwal ujian \\
& Nilai \\
& Hasil pembelajaran \\
& Piket guru \\
& Laporan akademik \\
\hline Pelepasan Siswa & Jenis pelepasan \\
& Siswa lulus \\
& Siswa keluar \\
& Siswa pindah \\
& Ijazah \\
& Raport \\
\hline Manajemen Tata Usaha & Guru \\
& Tenaga kependidikan \\
& Tenaga kerja honorer \\
& Jabatan \\
\hline Honor tenaga kerja \\
& Kepangkatan \\
& Absen \\
& Mutasi \\
\hline Laboratorium & Jadwal praktikum \\
& SoP \\
\hline & Inventaris asset \\
& praktikan \\
\hline & Anggota \\
& Peminjaman \\
& Pengembalian \\
& Buku \\
& Jenis buku \\
& Rak \\
& Laporan \\
\hline & Inventaris asset \\
& Pengadaan \\
& \\
\hline &
\end{tabular}

\section{d. Arsitektur Aplikasi}

Arsitektur Aplikasi adalah identifikasi kebutuhan pada sistem informasi sekolah, dimana ada banyak aplikasi pada setiap masisng-masing fungsi bisnis seperti pada table dibawah ini.

Tabel 2. Daftar Aplikasi

\begin{tabular}{|c|c|c|c|c|}
\hline No & Fungsi Bisnis & $\begin{array}{c}\text { Sistem } \\
\text { Informasi }\end{array}$ & $\begin{array}{c}\text { Kode } \\
\text { Aplikasi }\end{array}$ & Sistem Aplikasi \\
\hline \multirow[t]{3}{*}{1} & \multirow{3}{*}{$\begin{array}{l}\text { Penerimaan } \\
\text { Siswa Baru }\end{array}$} & \multirow[t]{3}{*}{ SI PSB } & AP 1.1 & Aplikasi Daftar Ulang \\
\hline & & & AP 1.2 & Aplikasi Pengolahan Tes \\
\hline & & & AP 1.3 & Aplikasi pembayaran iuran sekolah \\
\hline \multirow[t]{5}{*}{2} & \multirow{5}{*}{$\begin{array}{l}\text { Proses } \\
\text { Akademik }\end{array}$} & \multirow{5}{*}{$\begin{array}{l}\text { Sistem } \\
\text { informasi } \\
\text { akademik }\end{array}$} & AP 2.1 & Aplikasi Administrasi Kesiswaan \\
\hline & & & AP 2.2 & Aplikasi Penjadwalan \\
\hline & & & AP 2.3 & Aplikasi Administrasi PBM \\
\hline & & & AP 2.4 & Aplikasi Evaluasi Akademik \\
\hline & & & AP 2.5 & Aplikasi Pelaporan Akademik \\
\hline
\end{tabular}


Jurnal Riset Sistem Informasi Dan Teknik Informatika (JURASIK)

Volume 5 Nomor 1 Februari, pp 58-67

ISSN: 2527-5771/EISSN: 2549-7839

http://tunasbangsa.ac.id/ejurnal/index.php/jurasik

\begin{tabular}{|c|c|c|c|c|}
\hline No & Fungsi Bisnis & $\begin{array}{c}\text { Sistem } \\
\text { Informasi }\end{array}$ & $\begin{array}{c}\text { Kode } \\
\text { Aplikasi }\end{array}$ & Sistem Aplikasi \\
\hline \multirow[t]{2}{*}{3} & \multirow{2}{*}{$\begin{array}{l}\text { Pelepasan } \\
\text { Siswa }\end{array}$} & \multirow[t]{2}{*}{ SIA } & AP 3.1 & Aplikasi Alumni \\
\hline & & & AP 3.2 & Aplikasi Pelaporan Raport dan Ijazah \\
\hline \multirow[t]{4}{*}{4} & \multirow{4}{*}{$\begin{array}{l}\text { Manajemen } \\
\text { Tata Usaha }\end{array}$} & \multirow{4}{*}{$\begin{array}{l}\text { Sistem } \\
\text { Informasi Tata } \\
\text { Usaha }\end{array}$} & AP 4.1 & Aplikasi Kepegawaian \\
\hline & & & AP 4.2 & Aplikasi Absensi \\
\hline & & & AP 4.3 & Aplikasi Evaluasi Kinerja Pegawai \\
\hline & & & AP 4.4 & Aplikasi Pelaporan Tata Usaha \\
\hline \multirow[t]{2}{*}{5} & \multirow{2}{*}{$\begin{array}{l}\text { Manajemen } \\
\text { Sarana dan } \\
\text { Prasarana }\end{array}$} & \multirow[b]{2}{*}{$\begin{array}{l}\text { Sistem } \\
\text { Informasi } \\
\text { Manajemen } \\
\text { Sarana dan } \\
\text { Prasarana }\end{array}$} & AP 5.1 & Aplikasi Inventarisasi \\
\hline & & & AP 5.2 & Aplikasi Monitoring dan Evaluasi \\
\hline 6 & Laboratorium & $\begin{array}{l}\text { Sistem } \\
\text { Informasi } \\
\text { Laboratorium }\end{array}$ & AP 6.1 & Aplikasi Administrasi Laboratorium \\
\hline \multirow{4}{*}{7} & \multirow{4}{*}{ Perpustakaan } & \multirow{4}{*}{$\begin{array}{l}\text { Sistem } \\
\text { Informasi } \\
\text { Perpustakaan }\end{array}$} & AP 7.1 & Aplikasi Pendafataran Anggota \\
\hline & & & AP 7.2 & Aplikasi Pengolahan Data Buku \\
\hline & & & AP 7.3 & Aplikasi Peminjaman/Pengembalian Buku \\
\hline & & & AP 7.4 & Aplikasi Pelaporan \\
\hline
\end{tabular}

\section{e. Portofolio Aplikasi}

Portofolio Aplikasi bertujuan untuk melengkapi proses penentuan aplikasi dalam hubungannya dengan fungsi - fungsi bisnis. Tiap aplikasi yang didefinisikan dalam arsitektur aplikasi memiliki kontribusi terhadap bisnis bagi enterprise. Berdasarkan analisis portofolio aplikasi yang dikemukakan oleh ward aplikasi ini dibedakan menjadi 4 jenis, yaitu:

Tabel 3. Portofolio Aplikasi

\begin{tabular}{|l|c|}
\hline \multicolumn{1}{|c|}{ Strategi } & Potensi Tinggi \\
\hline Aplikasi Daftar Ulang PSB & Aplikasi Pencatatan Alumni \\
\cline { 1 - 1 } Apilkasi Pengolahan Ujian PSB & \\
\hline Aplikasi evaluasi kinerja pegawai & \\
\hline
\end{tabular}

\begin{tabular}{|l|l|}
\hline \multicolumn{1}{|c|}{ Strategi } & \multicolumn{1}{c|}{ Potensi Tinggi } \\
\hline Aplikasi Administrasi Kesiswaan & Aplikasi Kepegawaian \\
\hline Aplikasi Pembayaran Iuran Sekolah & Aplikasi Absensi \\
\hline Aplikasi Penjadwalan Mata Pelajaran & Aplikasi Tata Usaha \\
\hline Aplikasi Pelaporan Akademik & Aplikasi Inventaris Sekolah \\
\hline Aplikasi Pelaporan Raport dan Ijazah & Aplikasi Monitoring dan Evaluasi SarPras \\
\hline Aplikasi Administrasi Laboratorium & Aplikasi Evaluasi Akademik \\
\hline & Aplikasi Perpustakaan \\
\hline
\end{tabular}

Berdasarkan tabel 3 diatas Dapat diidentifikasikan bahwa jumlah aplikasi yang dibutuhkan untuk mengelola data dan mendukung fungsi bisnis berdasarkan kebutuhan informasi di tiap fungsi bisnis sebanyak 21 aplikasi. Berikut Solusi Aplikasi dari Sistem Informasi Sekolah pada gambar di bawah ini: 


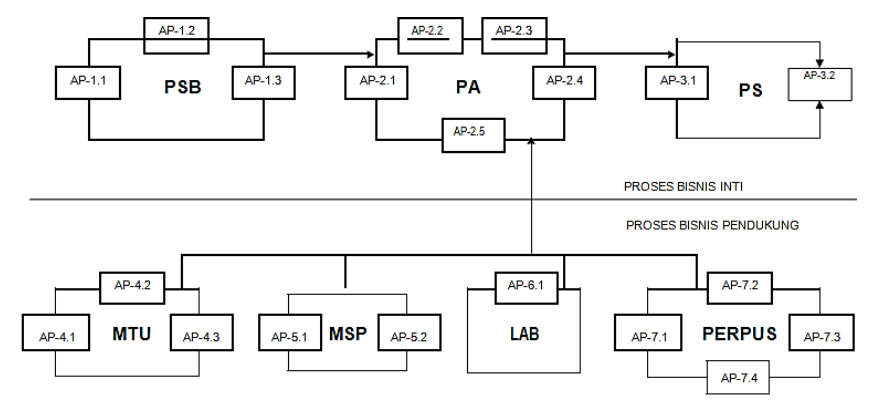

Gambar 4. Solusi Aplikasi

Arsitektur sistem aplikasi dapat dimodelkan menggunakan application landscape yang tersaji dalam gambar dibawah ini:

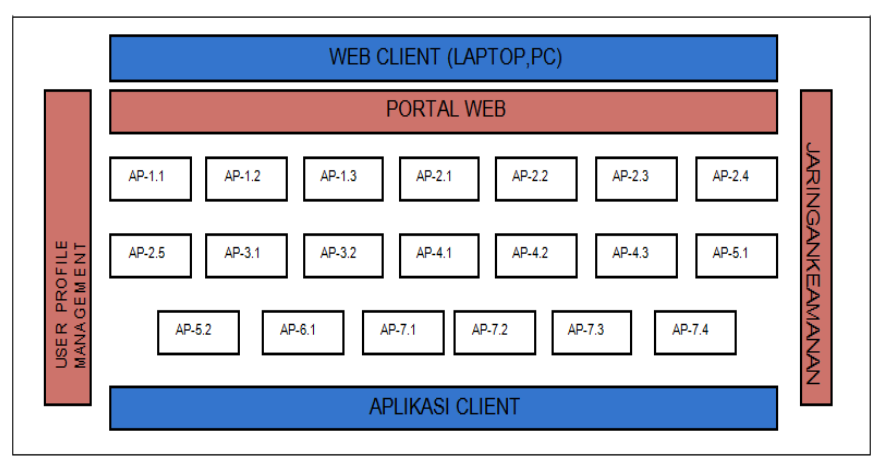

Gambar 4. Arsitektur Sistem Aplikasi

\section{f. Arsitektur Teknologi}

Arsitektur Teknologi merupakan rancangan mengenai teknologi yang digunakan pada sekolah tersebut contohnya adalah topologi jaringan dibawah ini.

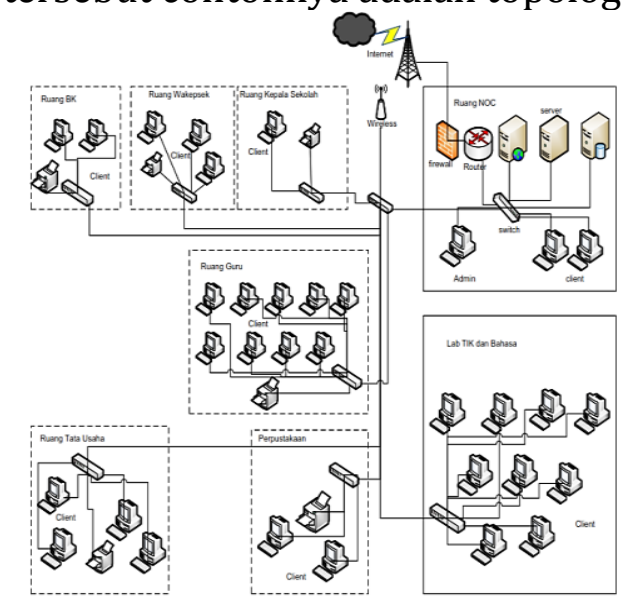

Gambar 5. Topologi Jaringan

Topologi jaringan yang dibangun dengan server pusat yang berada pada Ruang NOC dimana terdapat juga Router dan Firewall. Dari server ini, nantinya akan terhubung pada Ruang Kepala Sekolah, Ruang Wakasek, Ruang BK, Ruang Guru, Lab TIK dan Bahasa, Perpustakaan dan Ruang Tata Usaha. 


\section{SIMPULAN}

Berdasarkan bab sebelumnya yakni hasil penelitian dan pembahasan, maka dapat diperoleh kesimpulan sebagai berikut :

a) Aktivitas bisnis pada Arsitektur Sistem Informasi Sekolah terbagi menjadi dua yaitu aktivitas utama dan aktivitas pendukung. Aktivitas utama terdiri dari penerimaan siswa baru, proses akademik dan pelepasan siswa. Aktivitas pendukung meliputi manajemen tata usaha, manajemen sarana dan prasarana, perpustakaan dan laboratorium.

b) Pengembangan aplikasi baru perlu di integrasikan dengan aplikasi yang sudah ada untuk membentuk integrasi dalam mendukung bisnis dan menyediakan data dan informasi yang dibutuhkan oleh setiap unit bagian.

c) Perencanaan arsitektur teknologi menghasilkan sebuah jaringan enterprise secara konseptual yang memungkinkan terjadinya sharing data antar unit bagian.

d) Arsitektur sistem informasi yang terbentuk dapat digunakan sebagai panduan dalam pengembangan sistem informasi dalam hal pengolahan data dan informasi dalam aktivitas bisnis Sekolah.

e) Arsitektur Sistem Informasi Sekolah digunakan sebagai panduan untuk mengembangkan sistem-sistem informasi selanjutnya dalam upaya mendukung kinerja sekolah menjadi lebih maju.

f) Untuk mendapatkan model arsitektur enterprise yang lebih lengkap harus dilakukan penelitian lebih lanjut sampai pada tahapan akhir dalam TOGAF ADM

\section{DAFTAR PUSTAKA}

[1] The Open Group. (2011). TOGAF Version 9.1. United Kingdom: Van Haren Publishing

[2] Kadir, Abdul. 2014. Pengenalan Sistem Informasi Edisi Revisi. Yogyakarta: Andi.

[3] Krismaji. 2015. Sistem Informasi Akuntansi. Yogyakarta: UPP AMP YKPN.

[4] Scott, B. (2004) An Introduction to Enterprise Architecture.

[5] Minoli, Daniel. (2008). Enterprise Architechture A to Z Framework, Business Process Modeling, SOA, and Infrastructure Technology. Taylor \& Francis Group, LLC. Boca Raton London New York.

[6] Sutabri, Tata. (2012). Konsep Sistem Informasi. Yogyakarta: ANDI.

[7] Yunis, Roni dan Kridanto Surendro. (2009). Perancangan Model Enterprise Architecture Dengan Togaf Architecture Development Method. Jurnal Seminar Nasional Aplikasi Teknologi Informasi (SNATI).

[8] Ward, J. and J. Peppard. (2002). Strategic Planning for Information Sistems. West Sussex, England: John Wiley and Sons, Ltd. 